DOI $10.37882 / 2500-3682.2020 .12 .34$

\title{
АНАЛИЗ ДЕЛОВЫХ И ЛИЧНОСТНЫХ КАЧЕСТВ ЭФФЕКТИВНОГО РУКОВОДИТЕЛЯ
}

\section{ANALYSIS OF BUSINESS AND PERSONAL QUALITIES OF AN EFFECTIVE MANAGER \\ N. Sushko}

Summary: A competent company Manager can organize work correctly, build a development strategy, and fully manage employees and the organization as a whole. That is why it is so important to understand what business and personal qualities an ideal Manager should have. business qualities are not separable from personal qualities, and their consideration should be cumulative. In the article, the author analyzes the main business and personal qualities of an effective Manager and, not least, considers the limitations that prevent the full implementation of the qualities.

Keywords: business qualities of a Manager, effective Manager, personal qualities of a Manager. $\mathrm{y}$ правлять компаний может только грамотный руководитель, знающий свое дело, но кроме профессиональных качеств, включающих его опыт и знания как специалиста в своей сфере деятельности, знания внутренних процессов производства, он обязательно должен обладать рядом деловых и личностных качеств. Совокупность этих качеств позволит руководителю организовать работу, эффективно руководить людьми и строить стратегию развития организации.

К деловым качествам руководителя относят: знание структурного строения компании; навыки общения и управления; умение контролировать действия подчиненных, координировать их между собой; умение вести переговоры с партнерами, а также настраивать дружеский лад с подчиненными.

К личностным качествам относится целый комплекс личных, моральных и нравственных устоев человека, особенности его воспитания, индивидуальные особенности, характер, темперамент и т.д. Стиль управления компанией зависит больше от личностных качеств. Мало быть просто профессионалом своего дела, эффективный руководитель должен развиваться по всем трем направлениям.

Успешный руководитель, обладая «деловой хваткой», объединяет в себе оперативные и стратегические качества, то есть он умеет в теории и на практике планировать, а также организовывать процесс стратегическо-

\author{
Суико Наталья Геннадьевна \\ К.nсх.н., дочент, Тихоокеанский государственный \\ университет, г. Хабаровск \\ nat135@mail.ru
}

Аннотация: Грамотный руководитель компании может правильно организовать работу, построить стратегию развития и полноценно управлять сотрудниками и организацией в целом. Поэтому так важно понимать, какие деловые и личностные качества должны быть у идеального руководителя, деловые качества не отделимы от личностных, рассмотрение их должно носить совокупный характер. В статье автором проанализированы основные деловые и личностные качества эффективного руководителя и, что не маловажно, рассмотрены ограничения, которые препятствуют полноценной реализации качеств.

Ключевые слова: деловые качества руководителя, эффективный руководитель, личностные качества руководителя.

го развития компании. В условиях быстрого принятия решений, сопровождающееся часто эмоциональнострессовым состоянием, важно объективно оценивать всю сложившуюся ситуацию, держать под контролем собственные эмоции и четко ставить первостепенные задачи перед подчиненными. Очень важно не просто выставлять задачи сотрудникам, но уметь их оптимизировать, расставляя в порядке приоритетности. Анализируя деловые, управленческие качества эффективного руководителя, выделим на наш взгляд основные:

- умение оперативно и объективно оценивать и анализировать информацию, мыслить, решать и действовать в сложившейся обстановке;

- разумно использовать различные ресурсы для решения поставленных задач;

- умение выстраивать эффективную стратегию развития;

- работать в режиме многозадачности;

- умение психологически грамотно оценивать сотрудников, выявлять их сильные и слабые стороны, распределять роли между ними;

- четкая расстановка задач между подчиненными, координирование работы всей компании;

- способность самостоятельно принимать объективные и обоснованные конкретным ситуациям решения;

- умение налаживать контакты и коммуникации с руководством, партнёрами и подчиненными и поддерживать их на высоком уровне;

- умение оперативно ориентироваться в какой бы 
то ни было ситуации;

- умение управлять мотивацией сотрудников к достижению целей и повышать организационную культуру;

- умение грамотно выражать свои мысли, ораторские способности.

Рассматривая качества эффективного руководителя важно понимать, что его деловые качества не отделимы от личностных, только совокупное их рассмотрение дает цельное представление об идеальном руководителе. Руководитель не может быть профессионалом во всех отраслях и по всем задачам (когда мы говорим о крупных компаниях), очень важно уметь делегировать свои полномочия и создавать эффективную команду.

Выделим на наш взгляд основные важные личные качества, которые должны быть у эффективного руководителя:
- целеустремленность и высокие амбиции, нацеленность на успех;

- стрессоустойчивость, уравновешенность и выдержка, без этих важных качеств становится невозможно принятие объективных решений, повышенная эмоциональность в данном случае - это качество неэффективного руководителя;

- требовательность, обязательность и умение брать на себя всю полноту ответственности. Данные качества вкупе с имеющимся авторитетом руководителя помогают держать в коллективе дисциплину и поддерживать выполнение должностных обязанностей на должном уровне;

- адекватная самооценка, не умея объективно оценивать самого себя человек не в состоянии адекватно оценить и других людей;

- новаторство, сюда же можно отнести креативность - важное в современных экономических ус-

Таблица 1.

Ограничения в эффективной деятельности руководителя

Ограничения

Отсутствие умения влиять на людей

Заторможенное личное развитие

Неспособность руководить или плохие органи-

Неумение формировать коллектив

Неясность личных целей руководителя, размытые личные ценности

Отсутствие творчества в работе заторские способности

Неумение обучать

\section{Характеристика}

Руководители, обладающие высоким уровнем влияния, имеют презентабельный внешний вид, уверены в себе, умеют грамотно излагать свои мысли и давать указания. Невлиятельный руководитель не имеет взаимопонимания с сотрудниками

Обладая способностью к саморазвитию, руководитель получает дополнительные теоретические знания и умеет применять их на практике

Эффективный руководитель должен уметь оптимально организовать трудовой процесс. Неправильно подобранные методы работы приводит к неуверенности работников и отсутствия у них удовлетворения от проделанной работы, снижается общая эффективность и моральное состояние коллектива

Формирование трудового коллектива должно происходить с учетом целей его членов и их интересов, и перенаправление интересов сотрудников на достижение целей компании

Руководитель, обладая неясными личными целями, не способен достичь успеха в управленческой деятельности, так как принятие каждодневных решений базируется на личных принципах и ценностях.

Важный элемент управленческой деятельности - повышение квалификации, эффективный руководитель способствует повышении компетентности своих сотрудников, непосредственно участвуя в обучении

Руководители, использующие в своей деятельности ситуационный (неопределенный) подход, способны играть много ролей, своевременно корректировать свои действия в зависимости от сложившейся ситуации. Руководитель, не желающий экспериментировать, рисковать или сохранять творческий подход в работе, не способен заставить других творчески мыслить и использовать новые идеи в работе

Неумение принимать решения и решать проблемы

Эффективный руководитель способен правильно и быстро принимать решения

Неумение управлять собой, отсутствие самоконтроля

0бщение с сотрудниками должно проходить только на основе уважения, эффективный руководитель должен уметь управлять собой и своими эмоциями. Неспособность контролировать себя, бороться со стрессовыми и конфликтными ситуациями приводит к не возможности полноценно управлять другими людьми

Непонимание специфики управленческого труда
Руководитель, не понимающий мотивацию своих работников, не может полноценно понять управленческий труд, важно понимать всю ценность эффективности своего управления другими людьми 
ловиях стремление к новому, к преобразованиям, а также готовность внедрять эти новые методы и идеи в процесс работы.

- самокритика и самоконтроль, не умея контролировать себя, невозможно контролировать других, тем более, когда речь идет о большом коллективе;

- уважение к окружающим (вне зависимости от занимаемой должности), тактичность в общении и коммуникабельность;

- настойчивость, упорство и решительность в решении повседневных и сложных вопросов компании;

- напоследок отметим довольно редко встречаю- щееся, но, тем не менее, тоже очень важное качество - объективность.

Проанализировав основные на наш взгляд деловые и личные качества эффективного руководителя, хотелось бы остановиться напоследок на ограничениях, которые препятствуют полноценной реализации всех возможностей руководителя и представить их в виде таблицы.

Кто такой эффективный руководитель? Это открытый, спокойный, обаятельный, внимательный и внушающий доверие человек, решительный, смелый, опытный, гибкий, ориентированный на результат и свободный от предрассудков.

\section{ЛИТЕРАТУРА}

1. Адаир Д. Психология лидерства / Джон Адаир; пер. с англ. М. Котельниковой. - Москва: Эксмо, 2008. - 342 с.

2. Вавилова Н.В. Личностные качества руководителя как фактор его карьерного роста на предприятии. // Известия Самарского научного центра Российской академии наук. - 2010. - Т. 12. - № 5-3. - С. 682-685.

3. Деркач А.А. Акмеология: личностное и профессиональное развитие человека. Кн. 1-5. / Деркач А.А. Акмеологические основы управленческой деятельности. Кн. 2. - М.: РАГС, 2010. - 230 с.

4. Кричевский Р.Л. Психология лидерства: учебное пособие. - М.: Статут, 2007. - 541 с.

(с) Сушко Наталья Геннадьевна (nat135@mail.ru)

Журнал «Современная наука: актуальные проблемы теории и практики»

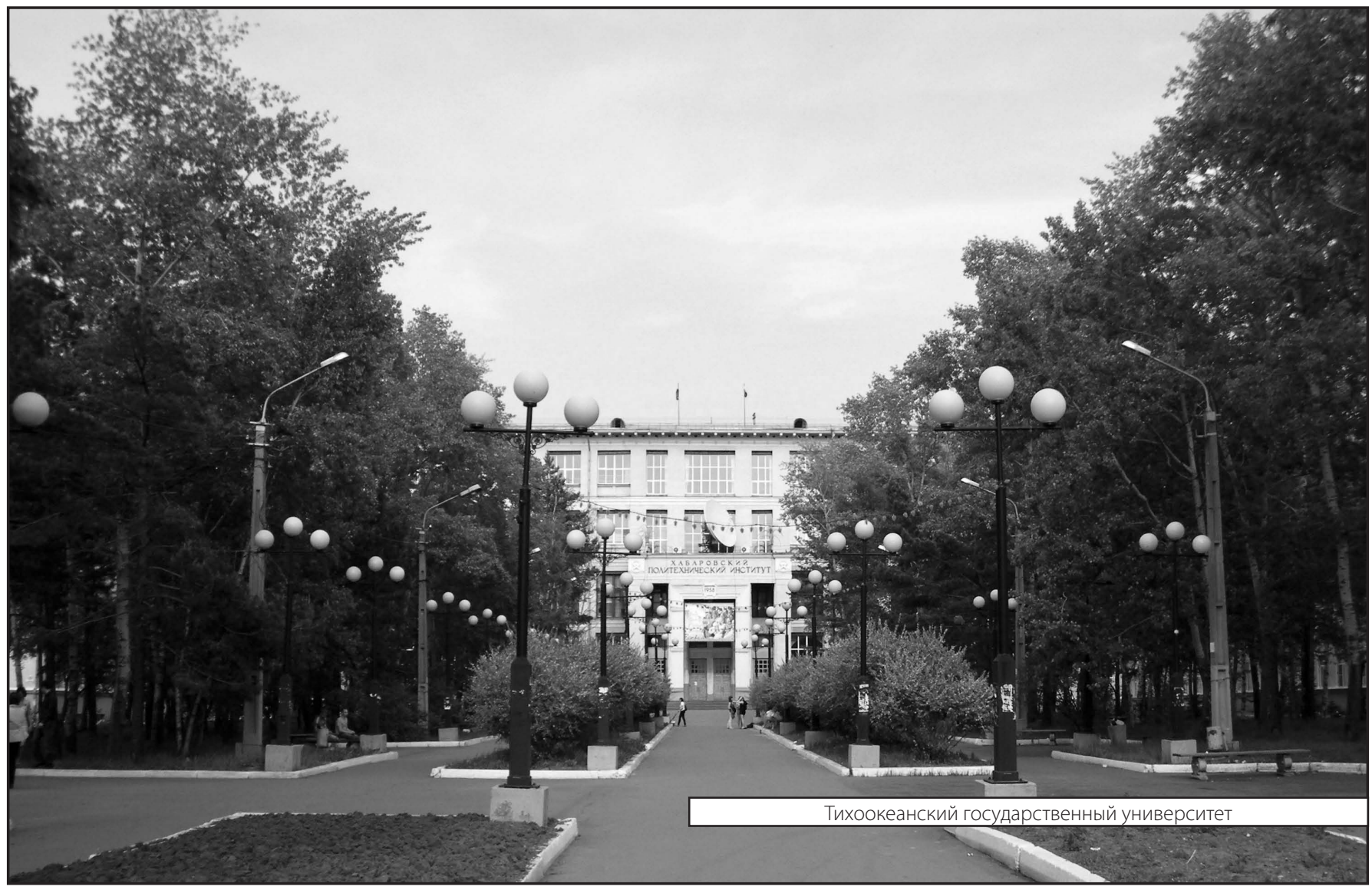

